\title{
4. 抗血小板抗体の検出と同定
}

埼玉県伊奈赤十字血液センター

森田庄 治

\section{目的}

輸血や妊娠などの同種免疫によって産生される抗血 小板抗体の存在は臨床上, 治療の妨げになることが多 い.

頻回血小板輸血によって引き起こされる血小板輸血 不応状態では主に抗 HLA 抗体が, また母児血小板型 不適合が原因で発症する新生児血小板減少性紫斑病で は主に抗 HPA 抗体が検出される．この両者を一つの 方法で同時に検出することはスクリーニング検查とし ての有用性は高い.

今回, オリンパス光学工業株式会社より, 従来の抗 血小板抗体検出用試薬に一部改良を加えた検出用試薬 anti-PLT・オリビオ・MPHA II（以下オリビオ II）が 発売されたので, 本キットの実用性について血小板固 相 MPHA 法と比較検討したので報告する.

\section{プレートの作製と検査法}

検討に用いたプレートは以下の手順により $\mathrm{O}$ 型 3 人の血液より作製した（表 1 )。オリビオ II（血小板抽 出抗原 ${ }^{122}$ 固相プレート） は全血から PRP を分離して 無菌生食水にて 3 回洗浄した後, 無菌生食水及び $5 \mathrm{mM}$ EDTA 無菌生食水で $4{ }^{\circ} \mathrm{C} 3$ 日間の抽出操作を行い, 抽 出後の上清についてタンパク濃度を測定し，これを希 釈後, 抽出抗原 3 人を Mix してモジュールプレート （96U）にラベリング，真空乾燥し作製した。 血小板固相プレートは MPHA 法 (改訂第 7 版) に準
じて 3 パネルを個々に作成した。オリビオ II は添付の 能書に, 血小板固相プレートは MPHA 法（改訂第 7 版）に従ってそれぞれ検査した。

\section{検討項目}

オリビオ II と血小板固相プレートの両者について以 下の項目について検討した。

1）非特異反応：

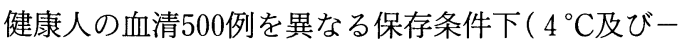
$\left.80^{\circ} \mathrm{C}\right)$ に分けてそれぞれ保存し，両者間での非特異反 応の有無を比較検討した。

2) 抗 HLA 抗体との反応性 :

輸血患者由来の抗 HLA 抗体を用いて，両者間での その反応性を比較し，さらにオリビオ II ではクロロキ ン処理による抗 HLA 及び抗 HPA 抗体の鑑別が可能 か否かについても検討した。

3）抗 HPA 抗体との反応性 :

各種の抗 HPA 抗体（抗 HPA1〜抗 HPA5及 び $\mathrm{Nak}^{\mathrm{a}}$ ) を用いて両者間での反応性を比較した.

4）輸血患者血清のスクリーニング :

輸血時に白血球除去フィルターを使用した輸血患者 血清552例（延べ）について両者でスクリーニングを行 い解析した。

5）抗 HPA 抗体の特異性同定：

クロロキン処理後においても反応性を示す血清につ いては血小板固相プレート 12 人により抗 HPA 抗体の

表 1 検討に用いた血小板の HLA 型及び HPA 型 ( 3 人)

\begin{tabular}{|c|c|c|c|c|c|c|c|c|c|c|c|c|c|}
\hline \multirow{2}{*}{$\begin{array}{l}\text { HLA 型及び } \\
\text { HPA 型 }\end{array}$} & \multicolumn{2}{|c|}{ HLA 型 } & \multicolumn{11}{|c|}{ HPA 型 } \\
\hline & A ローカス & B ローカス & $1 \mathrm{a}$ & $1 b$ & $2 \mathrm{a}$ & $2 b$ & $3 a$ & $3 b$ & $4 a$ & $4 \mathrm{~b}$ & $5 \mathrm{a}$ & $5 b$ & Nak-a \\
\hline パネル 1 & $\begin{array}{r}2(23.67) \\
26(10.94)\end{array}$ & $\underline{35(7.22)}$ & + & 0 & + & + & + & + & + & 0 & 0 & + & + \\
\hline パネル 2 & $\begin{array}{l}11(9.27) \\
33(7.48)\end{array}$ & $\begin{array}{l}44(7.43) \\
60(5.72)\end{array}$ & + & 0 & + & + & + & 0 & + & 0 & + & 0 & + \\
\hline パネル 3 & $\begin{array}{l}24(37.79) \\
26\end{array}$ & $\begin{array}{l}13(1.48) \\
52(11.31)\end{array}$ & + & 0 & + & 0 & + & + & + & + & + & 0 & + \\
\hline & & & & & & $\begin{array}{l}* 1 \\
* 2 \\
* 3\end{array}$ & & II & 小 & & を & $\begin{array}{l}\%) \\
\mathrm{Mi}\end{array}$ & 乙固相 \\
\hline
\end{tabular}


同定を行った.

結 果

1）非特異反応：

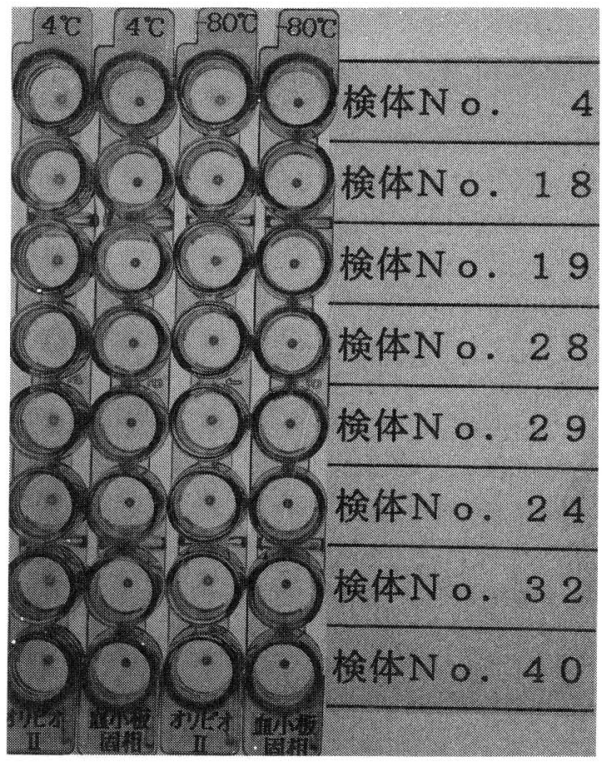

図 1 検体の保存による比較 $\left(4^{\circ} \mathrm{C}\right.$ vs $\left.-80^{\circ} \mathrm{C}\right)$

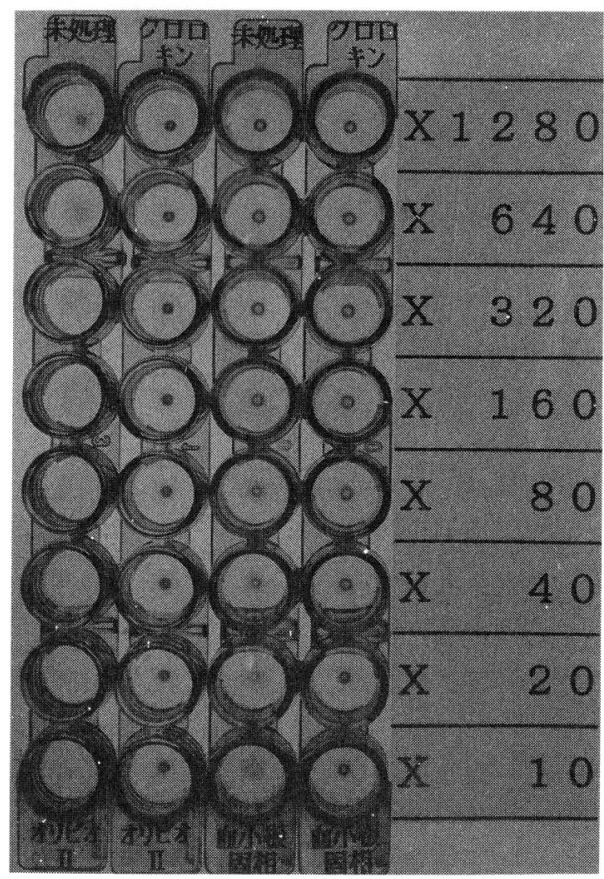

図 2 両者間での抗 HLA 抗体との反応性(未処理, ク ロロキン)
$4{ }^{\circ} \mathrm{C}$ 保存の血清500例中 5 例において,オリビオ II の みに非特異反応を認めた。また, $-80^{\circ} \mathrm{C}$ 保存の血清にお いてはオリビオII と血小板固相プレートの結果が完全 に一致し，非特異反応は認められなかった（図1）.

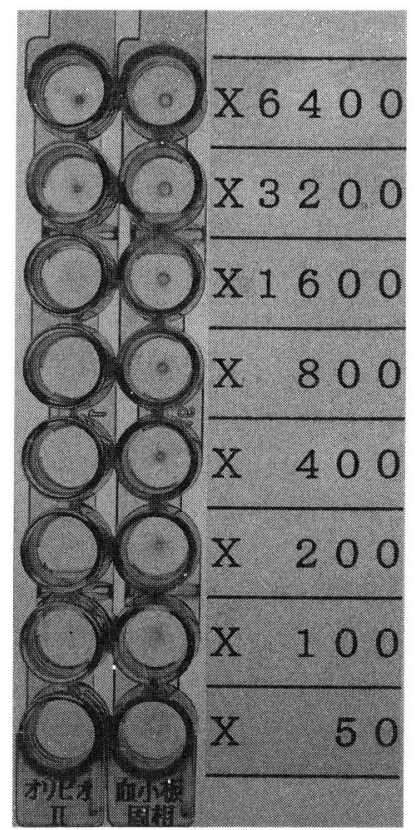

図 3 両者間での抗 HPA-1a 抗体との反応性

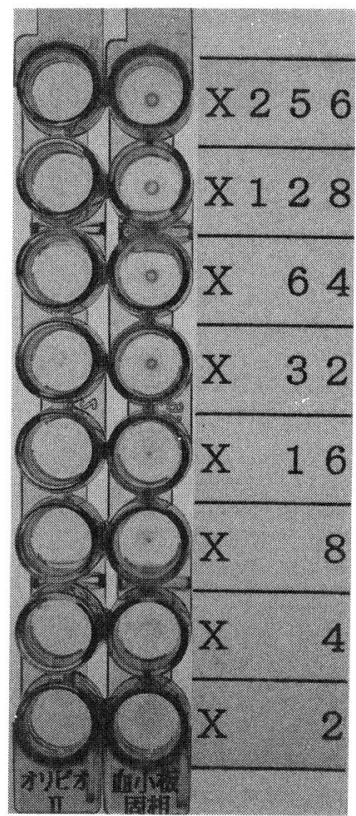

図 4 両者間での抗 HPA-4b 抗体との反応性 
2）抗 HLA 抗体との反応性：

抗 HLA 抗体を用いた両者間の比較では，未処理の オリビオ II は血小板固相プレートより高い検出率を示 した.

さらにオリビオ IIにクロロキンを加えることで, HLA 抗原の失活も比較的容易であった（図 2 ).

一部の非常に高力価を示す抗 HLA 抗体に抒いて は，血小板固相プレート以上にクロロキン処理時間を オリビオIIは必要とした。

3）抗 HPA 抗体との反応性 :

抗 HPA 抗体を用いた両者間の比較でも，オリビオ II は良好な反応性を示した。特に抗 HPA-1a, 抗 HPA$4 \mathrm{~b}$ ，抗 Naka抗体については非常に良好な反応性を示 した (図 3， 4, 5 ). 各抗 HPA 抗体との反応性の比 較（オリビオ II・血小板固相）を図 6 に示した。

4）輸血患者血清のスクリーニング：

輸血患者血清552例（延べ）について両者でスクリー ニングを実施した。陽性となった77例のうち27例がオ リビオ IIのみで陽性で，50例が共に陽性を示す結果で あった（表 2 ).

陽性となった77例について，オリビオ II，血小板固 相の両者によるクロロキン処理を行い，抗 HLA 抗体 と抗 HPA 抗体の鑑別を行った。

オリビオIIのみで陽性を示した27例のうちクロロキ ン処理後にも反応を示したのはわずか 1 例で，共に陽

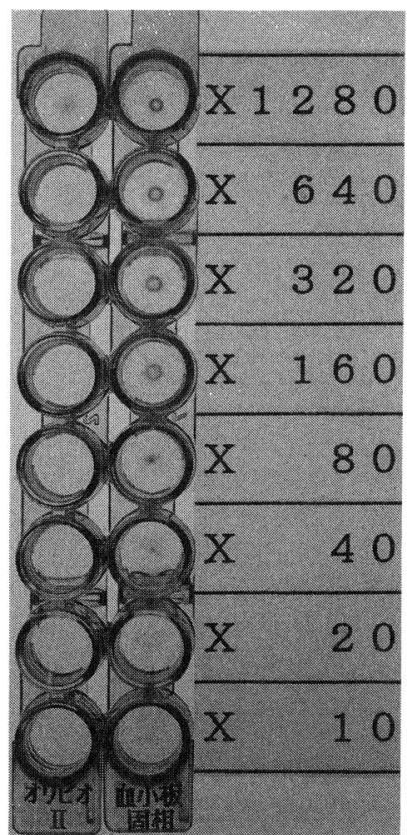

図 5 両者間での抗 $\mathrm{Nak}^{\mathrm{a}}$ 抗体との反応性

性を示した50例では処理後 4 例が反応を示した（表 3 ).これらは処理後反応が陰性化したことにより，抗 HLA 抗体と考えられた。

次にオリビオ II と血小板固相の両者と LCT 法との

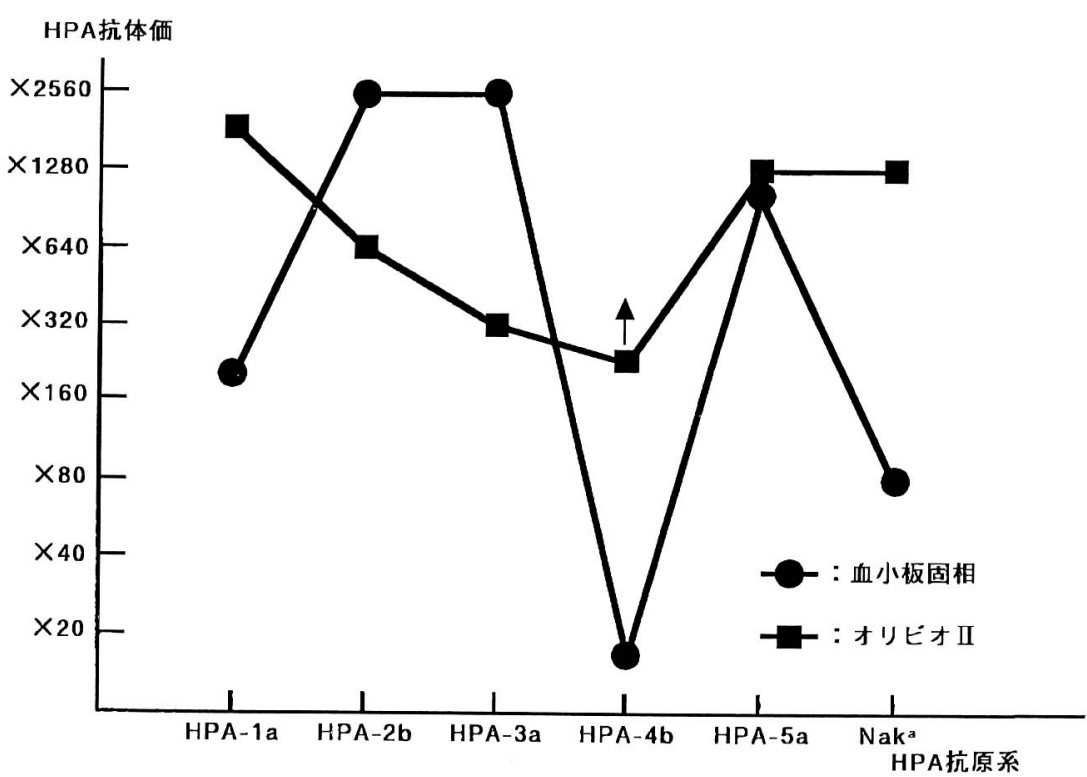

図 6 各抗 HPA 抗体との反応性の比較（オリビオ II・血小板固相） 
表 2 輸血患者552例のスクリーニング結果(クロロキ ン未処理)

\begin{tabular}{|c|c|c|c|c|}
\hline \multirow{2}{*}{\multicolumn{2}{|c|}{$\begin{array}{c}\text { クロロキン } \\
\text { 未処理 }\end{array}$}} & \multicolumn{2}{|c|}{ オリビオ II } & \\
\hline & & + & - & \\
\hline \multirow{2}{*}{$\begin{array}{l}\text { 血 } \\
\text { 板 } \\
\end{array}$} & + & 50 & 0 & 50 \\
\hline & - & 27 & 475 & 502 \\
\hline & & 77 & 475 & 552 \\
\hline
\end{tabular}

表 3 スクリーニング陽性77例の抗 HLA, 抗 HPA 抗 体の鑑別(クロロキン処理)

\begin{tabular}{|c|c|c|c|c|}
\hline \multirow{2}{*}{\multicolumn{2}{|c|}{$\begin{array}{c}\text { クロロキン } \\
\text { 処理 }\end{array}$}} & \multicolumn{2}{|c|}{ オリビオ II } & \\
\hline & & t & - & \\
\hline \multirow{2}{*}{$\begin{array}{l}\text { 血 } \\
\text { 板 }\end{array}$} & + & 4 & 0 & 4 \\
\hline & - & 1 & 72 & 73 \\
\hline & & 5 & 72 & 77 \\
\hline
\end{tabular}

表 4 LCT $50 \%$ 以上の反応率から見た 3 法の一致率

\begin{tabular}{c|c|c|c}
\hline & \multicolumn{3}{|c}{552 例 } \\
\hline 検査方法 & $\begin{array}{c}\text { オリビオII } \\
(3 \text { パネル })\end{array}$ & $\begin{array}{c}\text { 固相 } \\
(3 \text { パネ })\end{array}$ & $\begin{array}{c}\text { LCT } \\
(40 \text { パネル })\end{array}$ \\
\hline スクリーニング陽性 & $\begin{array}{c}77 \text { 例 } \\
(13.9 \%)\end{array}$ & $\begin{array}{c}50 \text { 例 } \\
(9.1 \%)\end{array}$ & $\begin{array}{c}174 \text { 例 } \\
(31.5 \%)\end{array}$ \\
\hline LCT50\%以上の反応率 & $\begin{array}{c}40 \text { 例 } \\
(63.5 \%)\end{array}$ & $\begin{array}{c}34 \text { 例 } \\
(54.0 \%)\end{array}$ & $\begin{array}{c}63 \text { 例 } \\
(100 \%)\end{array}$ \\
\hline
\end{tabular}

一致率について比較した。 あらかじめリンパ球40パネ ルを用いて552例についてスクリーニングを行い20パ ネル以上反応を示した血清との一致率を求めた. LCT 法で20パネル以上反応した血清は63例でこれを $100 \%$ とした場合，それぞれオリビオ IIが40例(63.5\%), 血 小板固相が34例（54.0\%）陽性となった（表 4).

今回検討に用いたプレート 3 人の HLA 抗原の頻度 は，表 1 にも示したように 3 人の A，B ローカスの抗 原頻度を全て合計するとそれぞれ $89 \% ， 33 \%$ に相当す ることからオリビオ II はわずか 3 人のパネルながら期 待値通りの検出率を示した.

5）抗 HPA 抗体の特異性同定：

オリビオ II及び血小板固相の両者でクロロキン処理 後にも反応を示した 4 例について血小板固相プレート による特異性同定を行い, 抗 HPA-5b 1 例と抗 GPIIb/IIIa 抗体 1 例が同定された. 他の 2 例は稀な血 小板型 (HPA-1b/b, 2b/b, 4b/b, 5b/b, 6b/b, Glanz- mann 血小板）を含めて全てに反応を示した.

\section{考察}

以上の結果から，オリビオ II は従来のものに比べ判 定の容易なことに加え, 少数検体にも十分対応が可能 となり実用面での改良が評価される．血小板固相プ レートとの比較した結果でも，総合的に同等かそれ以 上の結果を示した。特に両者による輸血患者血清のス クリーニングでは, 抗 HLA 抗体の検出率は血小板固 相プレートに比べ感度が高く，クロロキンによる抗 HPA 抗体と抗 HLA 抗体の鑑別も比較的容易であっ た.

これまで血小板輸血に関する検査は赤血球輸血検査 で実施されているような抗体スクリーニングなどに相 当するものがなく, 輸血前に患者と $\mathrm{ABO}$ 式血液型を 照合する程度で輸血する場合が多いので，通常は同種 免疫により抗血小板抗体が産生され，血小板輸血不応 答の状態となり初めて抗血小板抗体についての検索が 実施されることが多い.

検査が実施できない原因として，製剤の有効期限が 短いことに由来する時間的制約や，検査上の繁雑化が 多大の妨げになっていることから，より簡便で一般病 院規模でも十分検查が実施できるオリビオ II は血小板 輸血無効例の回避や血小板輸血効果の向上に有効な手 段と考えられる.

現在わかっているオリビオ II の唯一の改良点は, 今 回の結果からも明らかな様に, 輸血患者から検出され る抗血小板抗体の大部分は抗 HLA 抗体によるもので あることから，必然的にスクリーニング検査ではより 多数の抗 HLA 抗体の検出が臨床的に求められる.

現在のオリビオ II は数名の血小板抽出抗原を用いて 既知の抗 HPA 抗体及び抗 HLA 抗体を検出している ので, 数名の血小板抽出抗原で日本人の HLA 抗原の 大部分を組み入れることは難しく，早急に抗 HLA 抗 体が最大限検出できるように改善が望まれる.

また，スクリーニング検査の普及に伴い，検出され た抗体の特異性を同定するためのシステムも合わせて 要望する.

最後に本シンポジウムでは実用性の面からオリビオ II と血小板固相プレートによる基本的性能面について 比較検討した。さらにレトロスペクティブながら両者 を用いた輸血患者のスクリーニングを実施し，実践面 での比較検討を加えた．今後オリビオ IIが血小板輸血 効果といかなる相関を示すものか, プロスペクティブ スタディにより本キットの臨床面での有效性を明らか 
にしたい.

稿を終わるにあたり, 本研究は埼玉県伊奈赤十字血液セ ンター半戸啓一, 青木延雄, 埼玉県赤十字血液センター石島 あや子, 服部理男, 東大病院輸血部柴田洋一らとの共同研究 による。

また，本研究に際し御尽力いただきましたオリンパス光 学工業株式会社岡 秀教氏, 柿沼幸利氏, 狩野恭一氏に深謝 いたします。

\section{文献}

1) Shibata, Y., Juji, T., Tohyama, H., Sakamoto,
H., Ozawa, N., Kano, K.: Mixed passive hemagglutination with soluble platelet antigens. Int. Archs Allergy appl. Immun., 74 : 93-96, 1984.

2) Araki, N., Inaba, H., Nose, Y., Sakata, N., Ito, K., Shibata, Y.: Anti-HLA antibody screening with extracted platelet HLA antigens by the mixed passive hemagglutination method. Vox Sang. 69 : 222-230, 1995. 